\title{
Mytilus edulis as a quantitative indicator of dissolved cadmium. Final study and synthesis
}

\author{
Helmut Fischer
}

Ohlandbogen 9, D-2300 Altenholz, Federal Republic of Germany

\begin{abstract}
Juvenile blue mussels Mytilus edulis were cultivated in flow-through aquaria to investigate the influence of dissolved cadmium on cadmium accumulation (in terms of the Cd/shell-wt index). Where the ratio (by weight) of dissolved $\mathrm{Zn}$ to $\mathrm{Cd}$ remains within the range 25:1 to 60:1, accumulation of $\mathrm{Cd}$ is not significantly influenced by dissolved $\mathrm{Zn}$. Higher levels of concomitant $\mathrm{Zn}$ reduce the $\mathrm{Cd} /$ shellwt index. A lower ratio of $\mathrm{Zn}$ to $\mathrm{Cd}$ may slightly increase $\mathrm{Cd}$ accumulation. The $\mathrm{Cd} /$ shell-wt index is proportional to ambient levels of dissolved $\mathrm{Cd}$ up to $100 \mathrm{\mu g}^{-1}$ There were no significant effects on growth up to ca $30 \mu \mathrm{g} \mathrm{l}^{-1} \mathrm{Cd}$. Results corresponded to earlier experimental work and to field surveillance data reported in the literature. A procedure is suggested by which the concentration of dissolved $\mathrm{Cd}$ in natural environments may be estimated from 'mussel watch' data (Cd body burden, shell weight) and salinity. Cd accumulation in the mussel is described by the integral of the Cd/shell-wt index with growth of shells by weight. A model of biochemical accumulation of metals requires laboratory and field transplant experiments to be designed such that considerable growth is allowed in a new environment in order to approximate a new balance of metal residues in organisms in relation to ambient levels.
\end{abstract}

\section{INTRODUCTION}

The 'mussel watch' (Goldberg 1975) approach to coastal water quality control is based on the chemical analysis of contaminant residues in the tissues of bivalve molluscs. 'Mussel watch' programmes have been initiated in many parts of the world, but unreflected 'mussel madness' has received severe criticism (White 1984). It becomes increasingly clear that initial studies are required to prove the indicator ability of organisms to be used in monitoring: 'There is no justification for simply assuming that any new untested species can act as an efficient bio-indicator' (Phillips \& Segar 1986). The mussel is neither a new nor an untested indicator. Nevertheless it may be justified to concentrate research effort on this species. There is a rapidly growing amount of data from ongoing surveys using mussels, and a sound basis for interpretation of these data is urgently needed.

The investigations reported here represent the final phase of one research line on the mussel as an indicator of cadmium.

(1) The initial stage of this project was a methodological field survey. Results suggested that the shell weight of molluscs could be used as an independent variable in relation to the soft-tissue burden of cad- mium and other contaminants with long biological halflives. The so-called $\mathrm{Cd} / \mathrm{shell}$-wt index is independent of conditions such as nutritional state, spawning, or tidal exposure which produce much fluctuation in (conventional) soft-tissue concentration data (Fischer 1983).

(2) Laboratory cultivation studies on the influences of temperature, salinity, and dissolved oxygen provided experimental confirmation of the new approach, and an explanation of salinity effects on the $\mathrm{Cd}$ balance of mussels. The effect of salinity can now be quantified and eliminated. Results suggested further that growth of organisms must be included in the experimental design to approximate an equilibrated state of tissue residues in relation to environmental metal levels (Fischer 1986a).

(3) The experimental studies reported here refer to metal contamination. The similar chemical properties of the transition metals $\mathrm{Zn}$ and $\mathrm{Cd}$ mean that the former element requires special consideration with respect to interaction with $\mathrm{Cd}$ accumulation. Finally, the potential of mussels to indicate dissolved $\mathrm{Cd}$ is documented. A. procedure is suggested whereby the concentration of $\mathrm{Cd}$ in natural coastal environments may be estimated from 'mussel watch' data.

General considerations relate to a coherent methodology of empirical evidence, adequate model- 
ling, and experimental verification in research and field work on molluscs as biological indicators of contaminants.

\section{MATERIAL AND METHODS}

\section{Laboratory rearing}

Preparations. Juvenile blue mussels Mytilus edulis L. were selected from natural populations found on wooden pilings in Kieler Förde, Western Baltic Sea. They were adapted for $2 \mathrm{wk}$ to experimental conditions of temperature ( 15 to $16^{\circ} \mathrm{C}$, i.e. close to the optimum), salinity (15\%, corresponding to summer values in surface water of Kieler Bucht) and dissolved metals. Solutions of metal chlorides were added to give the desired concentrations of $\mathrm{Zn}$ and $\mathrm{Cd}$. The water was replaced every 3rd day after the mussels had cleared a suspension of green algae given as food. Where juvenile mussels were exposed to high levels of dissolved metals, their normal behaviour of crawling upwards and attaching to the substratum (the walls of glass beakers) was observed to be impaired after a few days. The lowest concentrations leading to this effect were chosen as the upper limits of metal dosage in the respective growth studies.

Cultivation. Healthy individuals were placed in small flow-through aquaria and exposed to dissolved heavy metals. The mussels were continuously fed an algal suspension until the majority had grown to 5 times their initial weight or more (Fig. 1).

Experimental water was prepared twice weekly from filtered (20 um mesh) natural seawater taken from Kieler Förde (containing ca $0.07 \mu \mathrm{g} \mathrm{l}^{-1} \mathrm{Cd}$ and $3 \mu \mathrm{g} \mathrm{l}^{-1} \mathrm{Zn}$; Kremling et al. 1979; a lower dissolved Cd level was measured in September 1984). Salinity was adjusted with deionized water and standard solutions of metal chlorides were added. The water was provided in poly-

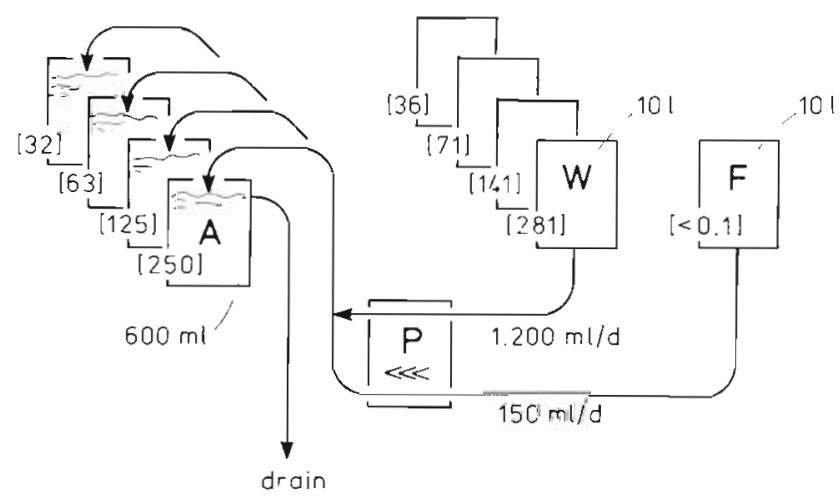

Fig. 1. Flow-through system for cultivating juvenile mussels in different concentrations of dissolved metals. W: water; F: feed algae chemostat; $\mathrm{P}$ : peristaltic pump; $\mathrm{A}$; aquaria. Brackets Some Cd concentrations as pre-determined from flow rates ethylene containers for continuous delivery by a peristaltic pump, together with an algal suspension as food.

Algal food was supplied from a chemostat culture of the coccal green Nannochloris sp., using nutrients according to Betz (1977) but strictly avoiding synthetic chelators. All aquaria in an experiment received the same amount of feed algae, corresponding to the same initial amount of Mytilus edulis biomass.

Flow rates were chosen to meet filtration rates of juvenile mussels as reported by Risgård et al. (1980). Test aquaria contained 10 to 20 individuais in a volume of $600 \mathrm{ml}$. Water exchange was up to $1200 \mathrm{ml} \mathrm{d}^{-1}$, plus $150 \mathrm{ml} \mathrm{d}^{-1}$ from algal feeding.

Metal concentrations were adjusted with commercial standard solutions (Merck ${ }^{(0)}$ ) according to measured flow rates of experimental water in relation to algae suspension. The coefficient of variation in the ratio between experimental water and algal food was 2.3 to $5.4 \%$. Filtration tests with ${ }^{109} \mathrm{Cd}$ and ${ }^{65} \mathrm{Zn}$ showed that (1) virtually all metal added ( $>97 \%$ ) remained in the 'dissolved' phase $(<0.4 \mu \mathrm{m})$, and (2) calculated metal concentrations can be relied upon within the precision of volumetric dosing.

\section{Analytical steps}

After $1 \mathrm{~d}$ without food in order to eliminate gut contents, the mussels were killed by wet heat at $60^{\circ} \mathrm{C}$. Soft tissue was removed from the shells and placed individually in polyethylene vials. Shells were dried overnight and weighed. Soft tissue was freeze-dried, ovendried at $100^{\circ} \mathrm{C}$ for $2 \mathrm{~h}$, and weighed. It was then digested in quartz test tubes, with loose teflon lids, by a 1:1 mixture of concentrated nitric and perchloric acids for $8 \mathrm{~h}$ at $220^{\circ} \mathrm{C}$ (which was found to be neccessary to analyse $\mathrm{Zn}$ - not the subject of this study). The samples were diluted with double-distilled water and analysed for $\mathrm{Cd}$ by flameless atomic absorption spectroscopy. Marine biological tissue reference material TORT-1 (National Research Council, Ottawa, Canada) was analysed to provide analytical quality control. Participation in the ICES 7 th Round Intercaljbration for Trace Metals in Biological Tissue indicated that results were acceptable (Berman \& Boyko 1987).

\section{Calculations}

Calculations are based on the dry weight of soft tissues and shells. Data differing from arithmetic means by more than 3 standard deviations were eliminated as outliers. Error terms in comparisons relate to the $95 \%$ confidence intervals of mean values.

Accumulation of $\mathrm{Cd}$ by the mussel is given in terms of the $\mathrm{Cd}$ /shell-wt index, i.e. the amount of $\mathrm{Cd}$ in the 
soft tissue in relation to the weight of the shells (Fischer 1983). Data relate to the respective experimental increments. Experimental data were not normalized to a standard individual size.

Before experiments were started, ca 20 juveniles were examined for shell weight as a function of shell length (Eq. 1), and for meat weight as a function of shell weight (Eq. 2). The coefficients were used to estimate the initial weight of soft tissue and shells of individuals grown under experimental conditions on the basis of their initial shell length.

$$
\begin{aligned}
& \text { shell } w t=a \text { shell length } \\
& \text { meat } w t=b \text { shell } w t
\end{aligned}
$$

Final weight divided by initial weight was calculated as a measure of growth under experimental conditions.

A condition index (CI) is given in terms of soft tissue as a percentage of total dry weight (Eq. 3)

$$
C I=\frac{\text { soft tissue wt }}{\text { soft tissue } w t+\text { shell wt }} \times 100
$$

\section{RESULTS}

\section{Influence of dissolved zinc on cadmium accumulation}

Experimental approach

Laboratory rearing experiments were performed with a basic $\mathrm{Cd}$ concentration of $1 \mu \mathrm{g} \mathrm{\textrm {l } ^ { - 1 }}$. Dosage of $\mathrm{Zn}$ was adjusted to result in ratios of $\mathrm{Zn}$ to $\mathrm{Cd}$ between $3: 1$ (no $Z n$ added) and 100:1 after dilution of water supply with algae suspension added as food. The final ratios of dissolved $\mathrm{Zn}$ to $\mathrm{Cd}$ (as calculated from measured flow rates) were somewhat different from those intended.

The experiments were terminated after $6 \mathrm{wk}$. By this time the pooled live weight of juvenile mussels had increased by factors of between 5 and 7 . Final shell length was ca $14 \mathrm{~mm}$, with an average weight of $80 \mathrm{mg}$ There was no mortality.

\section{Observations}

Cadmium accumulation. Cadmium accumulation by mussels, in terms of the $\mathrm{Cd} /$ shell-wt index, was modified by the ratio of dissolved $\mathrm{Cd}$ to $\mathrm{Zn}$ (Fig. 2). Tissue residues in relation to shell weight were slightly increased over the control group (no Zn added) when excess $\mathrm{Zn}$ was present in a ratio to $\mathrm{Cd}$ of ca 15:1 by weight (corresponding to a molar ratio of $30: 1$ ). When the ratio of dissolved $\mathrm{Zn}$ to $\mathrm{Cd}$ was in the range of $25: 1$ to $60: 1$ there was no significant difference in $\mathrm{Cd}$ accumulation. Higher levels of concomitantly dissolved

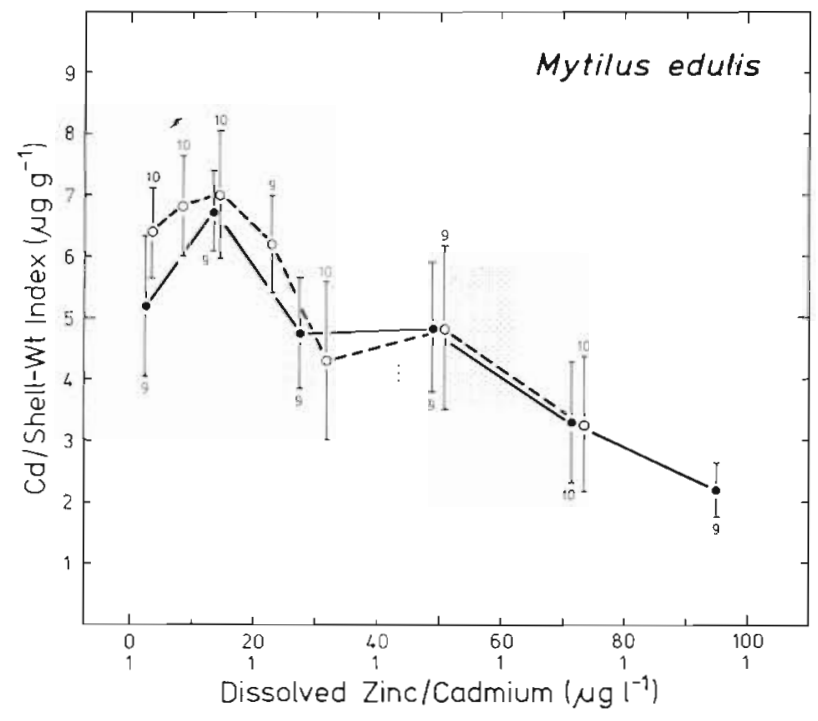

Fig. 2. Mytilus edulis. Effect of the ratio of dissolved $\mathrm{Zn}$ to $\mathrm{Cd}$ on $\mathrm{Cd}$ accumulation by mussels ( 6 wk cultivation, temperature 15 ${ }^{\circ} \mathrm{C}$, salinity $15 \%$ o). Where the ratio of these metals remains in a range often found in natural coastal environments (shaded), dissolved $\mathrm{Zn}$ has little effect on $\mathrm{Cd}$ accumulation by the mussel ( 2 experiments, $95 \%$ confidence intervals of means)

Zn depressed the Cd/shell-wt index of the mussel significantly $(p<0.05)$. A second experiment confirmed these findings.

Growth and condition. Data (Table 1) showed that the growth of juvenile mussels during laboratory cultivation was within the range observed in natural populations in the Kieler Förde (Boje 1965). Experimental increments of soft tissue were approximately the same in all experimental regimes. There were some significant $(p<0.05)$ differences in the calculated increases of shell weight. Greater experimental increments were recorded in mussels from the lowest level of dissolved $\mathrm{Zn}$, and reduced shell deposition was measured in specimens grown in $95 \mu \mathrm{g} \mathrm{l} \mathrm{l}^{-1} \mathrm{Zn}$ together with $1 \mathrm{ug} \mathrm{l}^{-1}$ $\mathrm{Cd}$. Condition indices were inversely correlated with differences in shell formation.

\section{Dependency of cadmium accumulation on ambient concentration}

Experimental approach

Dosage of cadmium chloride standard solution to experimental water was adjusted to produce a geometric sequence of $\mathrm{Cd}$ concentrations (factor 2) up to $500 \mu \mathrm{g} \mathrm{l}^{-1}$. This level of dissolved $\mathrm{Cd}$ had impaired crawling behaviour in the preliminary tests.

Laboratory cultivation was terminated after $9.4 \mathrm{wk}$. Pooled live weight of mussels exposed to the lower range of experimental Cd levels increased by ca $500 \%$ 
Table 1. Mytilus edulis juveniles, final length $14 \mathrm{~mm}$. Relative growth by weight (final/initial), and condition in different ratios of dissolved $\mathrm{Zn}$ to $\mathrm{Cd}$. Cultivation for $6 \mathrm{wk}$, temperature $15{ }^{\circ} \mathrm{C}$, salinity $15 \%$. Means $\pm 95 \%$ confidence intervals; $n=9$ throughout

\begin{tabular}{|c|c|c|c|c|c|c|c|}
\hline $\begin{array}{l}\text { Metals: } \\
\left(\operatorname{ugg} 1^{-1}\right)\end{array}$ & $\begin{array}{l}3 \\
1\end{array}$ & $\begin{array}{r}14 \\
1\end{array}$ & $\begin{array}{r}28 \\
1\end{array}$ & $\begin{array}{r}50 \\
1\end{array}$ & $\begin{array}{r}72 \\
1\end{array}$ & $\begin{array}{r}95 \\
1\end{array}$ & Grand mean \\
\hline Growth of meat $\left(W_{t} / W_{1}\right)$ & $\begin{array}{r}7.27 \\
+1.32 \\
\mathrm{~ns}\end{array}$ & $\begin{array}{c}6.96 \\
\pm 1.46 \\
\text { ns }\end{array}$ & $\begin{array}{r}7.29 \\
+2.12 \\
n s\end{array}$ & $\begin{array}{r}7.16 \\
\pm 3.02 \\
\text { ns }\end{array}$ & $\begin{array}{c}7.11 \\
\pm 1.44 \\
\text { ns }\end{array}$ & $\begin{array}{c}6.82 \\
\pm 1.12 \\
\mathrm{~ns}\end{array}$ & $\begin{array}{r}7.10 \\
\pm 1.75\end{array}$ \\
\hline Growth of shells $\left(\mathrm{W}_{\mathrm{f}} / \mathrm{W}_{1}\right)$ & $\begin{array}{r}7.31 \\
\pm 1.51 \\
\end{array}$ & $\begin{array}{r}5.65 \\
+1.30 \\
\text { ns }\end{array}$ & $\begin{array}{r}5.85 \\
+1.55 \\
n s\end{array}$ & $\begin{array}{c}6.54 \\
\pm 1.14 \\
\text { ns }\end{array}$ & $\begin{array}{r}5.87 \\
\pm 1.09 \\
\text { ns }\end{array}$ & $\begin{array}{r}4.92 \\
+0.65\end{array}$ & $\begin{array}{r}5.98 \\
\pm 1.27\end{array}$ \\
\hline Condition Index ( $\%$ meat) & $\begin{array}{r}14.5 \\
\pm 2.3\end{array}$ & $\begin{array}{c}17.4 \\
\pm 2.1 \\
\text { ns }\end{array}$ & $\begin{array}{c}18.2 \\
\pm \\
\pm .6 \\
\text { ns }\end{array}$ & $\begin{array}{c}17.2 \\
+2.0 \\
\mathrm{~ns}\end{array}$ & $\begin{array}{c}17.8 \\
\pm 2.8 \\
\text { ns }\end{array}$ & $\begin{array}{r}20.5 \\
\pm 2.0\end{array}$ & $\begin{array}{r}17.7 \\
\pm 2.9\end{array}$ \\
\hline
\end{tabular}

of initial weight. The final shell length was ca $12 \mathrm{~mm}$, with an average weight of $65 \mathrm{mg}$. All individuals exposed to $460 \mathrm{\mu g}^{-1}$ died by the $3 \mathrm{rd}$ week. Survival at the end of exposure to $220 \mu \mathrm{gg}^{-1}$ was $40 \%$, but 5 of 7 individuals decreased in soft-tissue weight.

\section{Observations}

Cadmium accumulation. The $\mathrm{Cd} /$ shell-wt index of mussels, calculated from experimental increments, was directly proportional to dissolved Cd (Fig. 3). Regression analysis of log-transformed data resulted in an intercept of $1.58 \pm 0.46$ (slope not significantly different from 1 ; $r=0.9919$ ). Hence, the Cd/shell-wt index of mussels grown in $1 \mu \mathrm{g} \mathrm{l}^{-1}$ dissolved Cd would be 4.85 with an asymmetric $95 \%$ confidence interval of 3.06 to 7.67. Linear regression analysis of non-transformed data gave a slope of $6.35 \pm 0.54(n=64$; intercept not significantly different from $0 ; r=0.9492$ ). This value corresponds to results of other rearing experiments (Fischer 1986a, this study, Fig 2). Similar data were obtained in a second experiment.

No reliable $\mathrm{Cd} / \mathrm{shell}$-wt index could be calculated from analytical data on mussels from $220 \mu \mathrm{g} \mathrm{l}^{-1}$ dissolved Cd because only 2 specimens had grown. Tissue concentration data of 7 individuals surviving at the end of experimental exposure indicated that Cd accumulation was disproportionately low

Growth and condition. Experimental increments in soft-tissues and shells were approximately the same in mussels grown in Cd levels up to $30 \mathrm{ug} \mathrm{l}^{-1}$ with the exception of significantly greater shell growth in $1.8 \mathrm{\mu g}$ $1^{-1}$ (correspondingly lower $\mathrm{CI}_{\text {; }}$ Table 2). Higher levels of dissolved $\mathrm{Cd}$ affected the growth of mussels, depending on the $\mathrm{Cd}$ concentration in the culture water. These mussels received more food in relation to their smaller size, which increased the CI. (Only 2 of 7 individuals surviving $9.4 \mathrm{wk}$ exposure to $220 \mu \mathrm{g} \mathrm{I}^{-1}$

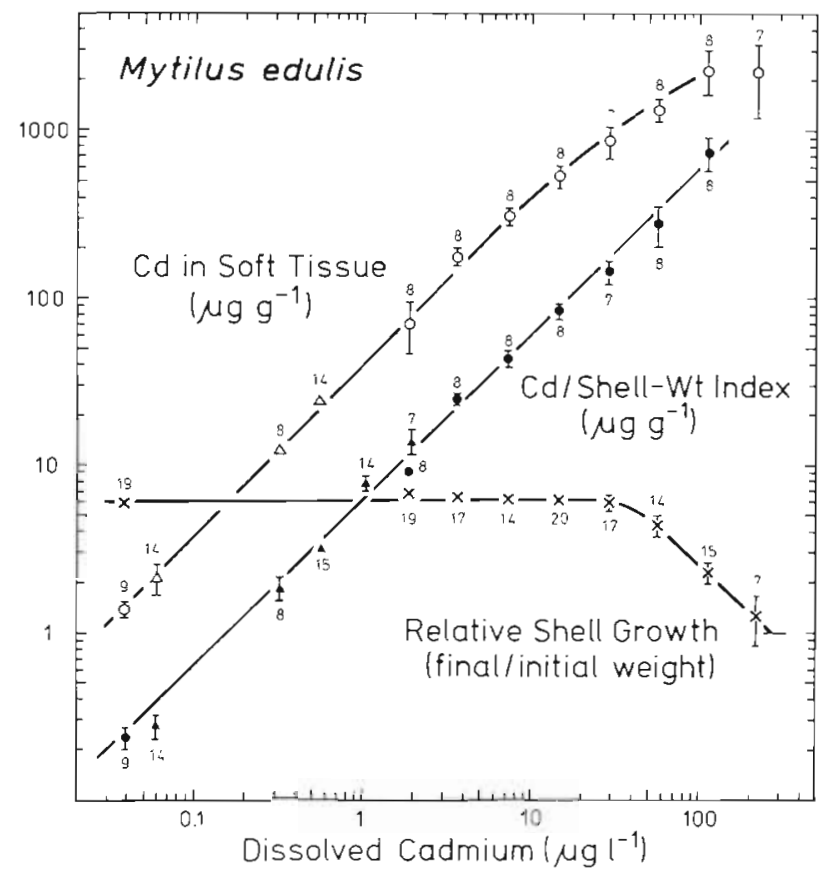

Fig. 3. Mytilus edulis. Effects of dissolved Cd on Cd accumulation and relative growth (9.4 wk cultivation, temperature $15{ }^{\circ} \mathrm{C}$, salinity $15 \%$ ). Cd accumulation is proportional to dissolved $\mathrm{Cd}$. Growth of shells by weight (final/initial) is not affected by dissolved $\mathrm{Cd}$ up to $40 \mu \mathrm{g} \mathrm{I}^{-1}(\mathrm{Cd} / \mathrm{shell}$-wt index calculated, other curves fitted by hand; $95 \%$ confidence intervals of means)

dissolved Cd remained able to utilize food. Their CIs were 18.6 and 19.3.)

\section{Significance of results}

\section{Approach}

Information concerning the significance of experimental results reported here is sought by (1) extrapolating experimental data to realistic environmental condi- 
Table 2. Mytilus edulis juveniles, final length $12 \mathrm{~mm}$. Relative growth by weight (final/initial), and condition in response to dissolved cadmium. Cultivation for $9.4 \mathrm{wk}$, temperature $15^{\circ} \mathrm{C}$, salinity $15 \%$. Means $\pm 95 \%$ confidence intervals; $n=15$ if not otherwise given

\begin{tabular}{|c|c|c|c|c|c|c|c|c|c|c|}
\hline $\begin{array}{l}\text { Cadmium: } \\
\left(\mu \mathrm{g} \mathrm{l}^{-1}\right)\end{array}$ & 0.04 & 1.8 & 3.7 & 7.2 & 15 & 29 & 57 & 110 & 220 & $\begin{array}{l}\text { Grand } \\
\text { mean }\end{array}$ \\
\hline Growth of meat $\left(W_{1} / W_{i}\right)$ & $\begin{array}{r}4.79 \\
\pm 0.43 \\
\mathrm{~ns}\end{array}$ & $\begin{array}{c}4.36 \\
+0.43 \\
\text { ns }\end{array}$ & $\begin{array}{c}4.98 \\
\pm 0.49 \\
\mathrm{~ns}\end{array}$ & $\begin{array}{c}4.43 \\
\pm 0.55 \\
\mathrm{~ns}\end{array}$ & $\begin{array}{r}4.77 \\
\pm 0.57 \\
\text { ns }\end{array}$ & $\begin{array}{c}4.96 \\
\pm 0.68 \\
n s\end{array}$ & $\begin{array}{r}3.88 \\
\pm 0.93\end{array}$ & $\begin{array}{r}2.31 \\
\pm 0.53\end{array}$ & $\begin{aligned} & 1.15 \\
\pm & 0.90 \\
& (7)\end{aligned}$ & $\begin{array}{r}4.72 \\
+0.53\end{array}$ \\
\hline Growth of shells $\left(W_{i} / W_{i}\right)$ & $\begin{array}{r}6.04 \\
\pm 0.53 \\
\text { ns }\end{array}$ & $\begin{array}{r}7.06 \\
\pm 0.58\end{array}$ & $\begin{array}{c}6.60 \\
\pm 0.62 \\
\text { ns }\end{array}$ & $\begin{array}{c}6.24 \\
\pm 0.51 \\
\text { ns }\end{array}$ & $\begin{array}{c}6.17 \\
\pm 0.73 \\
\text { ns }\end{array}$ & $\begin{array}{c}5.92 \\
\pm 0.78 \\
\mathrm{~ns}\end{array}$ & $\begin{array}{r}4.37 \\
\pm 0.71\end{array}$ & $\begin{array}{r}2.25 \\
\pm 0.36\end{array}$ & $\begin{array}{r}1.24 \\
\pm 0.42 \\
(7)\end{array}$ & $\begin{array}{r}6.19 \\
\pm 0.63\end{array}$ \\
\hline Condition Index ( $\%$ meat) & $\begin{array}{c}12.1 \\
\pm 0.8 \\
\text { ns }\end{array}$ & $\begin{array}{r}9.4 \\
\pm 0.5\end{array}$ & $\begin{array}{c}11.0 \\
\pm 0.6 \\
\text { ns }\end{array}$ & $\begin{array}{c}10.9 \\
\pm 1.1 \\
\text { ns }\end{array}$ & $\begin{array}{c}11.6 \\
\pm 0.7 \\
n s\end{array}$ & $\begin{array}{c}12.4 \\
\pm 0.7 \\
\mathrm{nS}\end{array}$ & $\begin{array}{c}12.9 \\
\pm 1.6 \\
\mathrm{~ns}\end{array}$ & $\begin{array}{r}15.8 \\
\pm 2.3\end{array}$ & $\begin{array}{c}12.3 \\
\pm 5.1 \\
(7)\end{array}$ & $\begin{array}{r}11.8 \\
\pm 0.9\end{array}$ \\
\hline
\end{tabular}

tions, and (2) recalculating observations from the field to the conditions of laboratory studies. Calculations relate to a $\mathrm{Cd} / \mathrm{sh}$ ell-wt index of $5 \mu \mathrm{g} \mathrm{g}^{-1}$. This is the experimental value of mussels grown in $1 \mu \mathrm{g} \mathrm{l}^{-1} \mathrm{Cd}$ (Fig. 3), corrected for a realistic excess of dissolved $\mathrm{Zn}$ with respect to $\mathrm{Cd}$ (Fig. 2, shaded).

\section{Comparative evaluation}

Extrapolation of experimental observations. Analytical data can be recalculated for most salinities relevant to mussel watch programmes, because the $\mathrm{Cd} /$ shell-wt index is inversely proportional to salinity in the range of 15 to $30 \%$ (slightly lower values at $35 \%$; Fischer 1986a). Hence the standard mussel (1 g shell) when grown in $30 \%$ salinity with $1 \mu \mathrm{g} \mathrm{l}^{-1}$ dissolved $\mathrm{Cd}$ would contain $2.5 \mu \mathrm{g} \mathrm{Cd}$ in its soft tissues. Coastal seawater contains ca $50 \mathrm{ng} \mathrm{l}^{-1}$ dissolved $\mathrm{Cd}$. Since values are proportional, the corresponding $\mathrm{Cd}$ /shell-wt index is $0.13 \mu \mathrm{g} \mathrm{g}^{-1}$. Assuming a value of 7 for the ratio between shell weight and meat dry weight, the corresponding soft-tissue $\mathrm{Cd}$ concentration would be $0.9 \mu \mathrm{g} \mathrm{g}^{-1}-\mathrm{a}$ Cd concentration commonly encountered in the mussel.

Recalculation of field data. In addition to data referred to previously (Fischer 1986a), further information from field surveys is found in the literature. Original data have been recalculated for the conditions of this study as follows (Table 3). Hypothetical Cd/shell-wt indices were calculated from soft-tissue concentration, assuming ratios of shell:meat according to sampling sites and seasons reported. These values were corrected for $15 \%$ salinity and divided by original data on dissolved $\mathrm{Cd}$. Hence, the recalculated data relate to $1 \mu \mathrm{g} \mathrm{l}^{-1} \mathrm{Cd}$ in $15 \%$ salinity. They are close to the $\mathrm{Cd} /$ shell-wt index of mussels experimentally grown in this regime (this study).

\section{DISCUSSION AND CONCLUSIONS}

\section{Influence of dissolved zinc on cadmium accumulation}

The possibility of interactions between contaminants on accumulation is a major source of uncertainty in the 'mussel watch' approach to environmental monitoring (Phillips 1980). Cd and Zn have similar chemical properties. The existence of functional interrelationships (reviews: Vallee \& Ulmer 1972, Kägi \& Nordberg 1979) suggest interdependencies concerning body burdens.

The controlled growth experiments reported here confirm that $\mathrm{Cd}$ is inadequately indicated by the mussel where disproportionately high levels of $\mathrm{Zn}$ increase the ratio between dissolved $\mathrm{Zn}$ and $\mathrm{Cd}$ (Bryan \& Gibbs 1983). Contamination dominated by $\mathrm{Cd}$ lowers this ratio and $\mathrm{Cd}$ accumulation may be slightly elevated. However, significantly higher $\mathrm{Cd} /$ shell-wt indices in mussels from $15 \mathrm{\mu g} \mathrm{l}^{-1} \mathrm{Zn}$ together with $1 \mathrm{\mu g} \mathrm{l}^{-1} \mathrm{Cd}$ could also result from a general stimulative effect of $\mathrm{Zn}$ on life functions (Vallee 1978) rather than from the ratio of $\mathrm{Zn}$ to $\mathrm{Cd}$ per se. Since the overall variability of individual data would swamp effects in the order of $25 \%$ of means, modification of Cd accumulation by a ratio of dissolved $\mathrm{Zn}$ to $\mathrm{Cd}$ lower than 'normal' (see below) is probably unimportant for 'mussel watch' programmes.

Coastal seawater contains $\mathrm{Zn}$ and $\mathrm{Cd}$ in a ratio (by weight) between 30:1 and 40:1 (Chester \& Stoner 1974, Boyden 1975, Kremling et al. 1979, NRCC 1985). A greater proportion of $\mathrm{Zn}$ has been measured in gross industrial and domestic effluents (e.g. IAWR 1980, LASH 1979-1982, Carlson 1986). A Zn:Cd ratio of 133:1 is considered typical for the North Sea coast of the United Kingdom (Department of the Environment 1987). In general, however, the ratio of $\mathrm{Zn}$ to $\mathrm{Cd}$ in nearshore seawater appears to remain in a range where the accumulation of $\mathrm{Cd}$ by the mussel is not significantly modified by changes of this ratio (Fig. 2, shaded). 
Table 3. Mytilus edulis as an indicator of cadmium. Tissue concentration data in relation to dissolved Cd, from the literature, recalculated for (hypothetical) $\mathrm{Cd}$ /shell-wt indices under standard conditions of $15 \%$ salinity and $1 \mathrm{\mu g} \mathrm{l^{-1 }} \mathrm{Cd}^{-}$

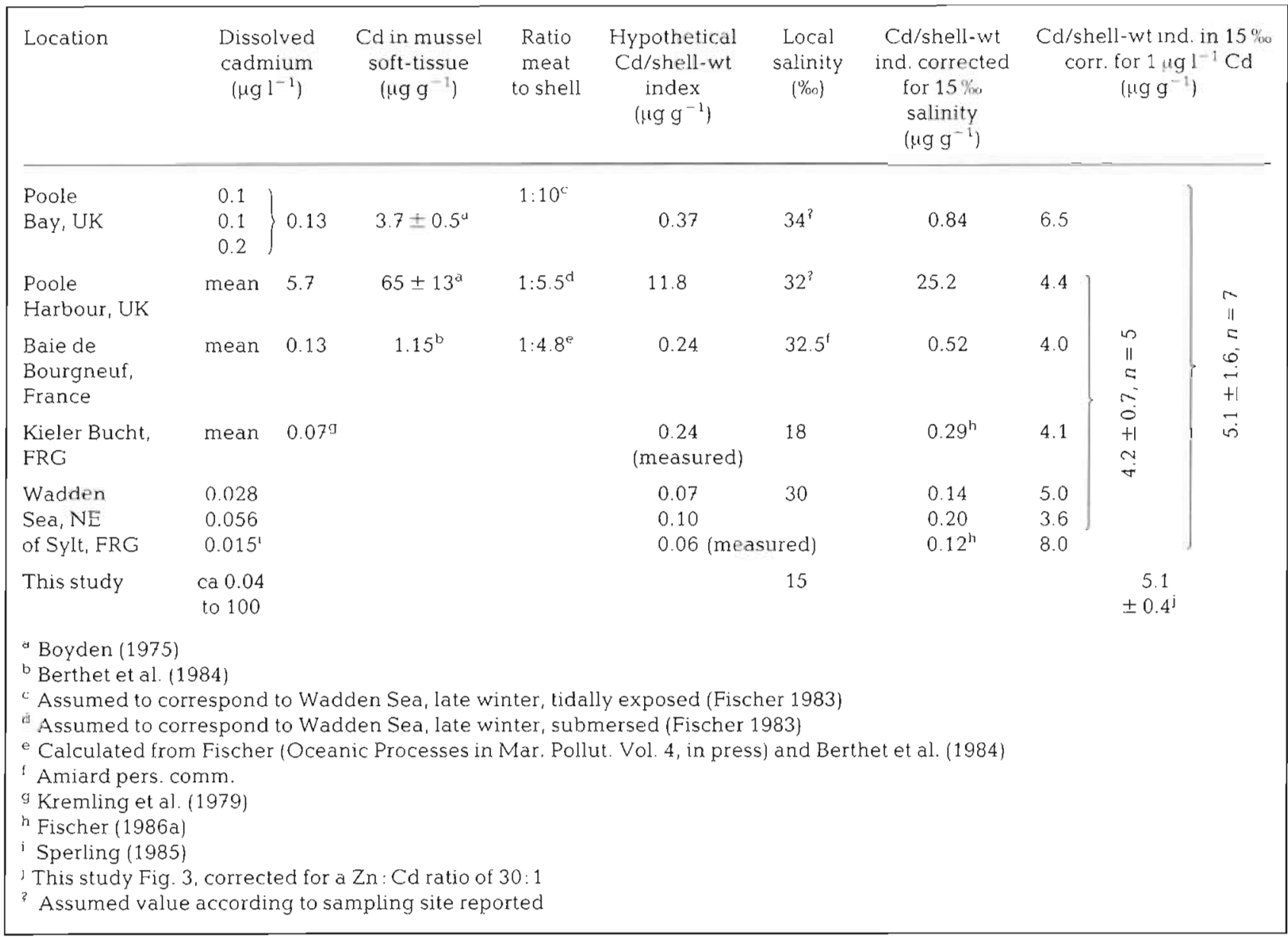

\section{Dependency of cadmium accumulation on ambient concentration}

Biological contaminant monitoring depends on a positive interrelation between residues in organisms and environmental contamination. Ideally, there should be a proportional interrelation with a constant slope to allow a numerical estimate of environmental contaminant levels on the basis of residues in biota.

This study provides experimental evidence that $\mathrm{Cd}$ accumulation by the mussel is proportional to dissolved $\mathrm{Cd}$ from baseline levels found in coastal waters to concentrations inhibiting growth. The capacity of mussels to bind and store $\mathrm{Cd}$ is illustrated by tissue concentrations as high as $1000 \mu \mathrm{g} \mathrm{g}^{-1}$ without notable effects on growth. The corresponding $\mathrm{Cd} /$ shell-wt index was $200 \mathrm{ug} \mathrm{g}^{-1}$ This is 3 orders of magnitude higher than that found in mussels from the Western Baltic Sea (Fischer 1986c).

It has been emphasized before (Fischer 1986a) that the normal physiological functions of organisms must be sustained if reliable information is sought from experimental studies. The observation of lower $\mathrm{Cd}$ accumulation from detrimental ambient levels (Fig. 3) may be interpreted correspondingly. In this context, it is possible that toxic ambient $\mathrm{Zn}$ levels may affect $\mathrm{Cd}$ accumulation irrespective of the $\mathrm{Zn}$ : Cd ratio (laboratory tests: Phillips 1976, Jackim et al. 1977; field exposure: Bryan \& Gibbs 1983; laboratory growth study: Fischer 1986b).

If the potential of organisms to monitor dissolved metals is limited under conditions ultimately lethal to them, it could be misleading to emphasize the hardiness of mussels to survive in the laboratory as a basic pre-requisite for an indicator organism (e.g. Phillips 1980). The amount of knowledge produced on the short-term performance of dying, diseased, shocked and malnourished marine animals is impressive' (Kinne 1984), and there is probably no acute need to increase it further The opposite view may be seen in the original argument of Butler et al. (1971): Molluscs adapt readily to laboratory culture (emphasis mine) and can 
be transplanted to field stations varying quite widely in hydrographic conditions'. Maintenance for scientific purposes has been classified as a minimum level of cultivation techniques (Kinne 1970). General usage of the term implies improvement, development, and growth.

\section{Significance of results}

The experimental design of the studies reported here corresponds to the standard monovariable approach of laboratory investigations. Results of $\mathrm{Cd}$ accumulation (Fig. 3) are ca $20 \%$ higher than they would be if $\mathrm{Zn}$ had been present in a realistic excess with respect to $\mathrm{Cd}$ (Fig. 2). Experimental results corrected for this value correspond to data from field investigations. In addition to the conclusions on the influence of $\mathrm{Zn}$, this suggests that interactions with other metals present in the natural environment may not be very important in general.

\section{Quantitative bio-monitoring of dissolved cadmium}

Research on Cd accumulation by the mussel has reached a stage where it appears feasible to estimate dissolved $\mathrm{Cd}$ concentrations in coastal water from 'mussel watch' data. The basic data required are: $\mathrm{Cd}$ burden of soft tissues ( $\mathrm{kg}$ ), weight of the shells (g), and average salinity of the sampling site (\%). The ratio (by weight) between dissolved $\mathrm{Zn}$ and $\mathrm{Cd}$ should be within 25 to 60 . Calculatory steps are as follows.

- Calculate the Ca/shell-wt index $\left(\mu \mathrm{g} \mathrm{g}^{-1}\right)$

- Correct average salinity of sampling site:

Multiply (1) by reference salinity $(15 \%)$ and divide by average salinity of sampling site (\%) to yield the $\mathrm{Cd} / \mathrm{sh}$ ell-wt index in $15 \%\left(\mu \mathrm{g} \mathrm{g}^{-1}\right)$

- Estimate average dissolved $\mathrm{Cd}$ of sampling site:

Divide (2) by the reference value of $5\left(\mu \mathrm{g} \mathrm{g}^{-1} /\right.$

$\left.\mu \mathrm{g} \mathrm{l}^{-1}\right)$ to yield dissolved $\mathrm{Cd}\left(\mu \mathrm{g} \mathrm{l}^{-1}\right)$

The bias of the procedure suggested here is assumed to be within $20 \%$. Residual variability of field data is in the same range if sample size is small, i.e. ca 10 individuals. Considering this degree of uncertainty, estimating chemical water quality by means of biological indicators appears to be outdated by the rapid advances in analytical marine chemistry. It may be recalled, however, that changes in average contaminant levels cannot be detected by sporadic water analyses - a principal limitation of the water chemistry approach which gave rise to the 'mussel watch' concept (Goldberg et al. 1978).

\section{GENERAL CONSIDERATIONS}

\section{Methodological problems in contaminant monitoring}

Though many exceptions give rise to questioning the 'mussel watch' idea from a scientific point of view, general experience from field surveys suggest that metal levels in molluscs come to reflect those in coastal seawater. Obviously some equilibrium does exist between organisms and their natural environment. Experimental studies, however, have not been successful in providing corresponding evidence. Tissue concentrations increased throughout exposure periods, even in the longer-term studies with low dissolved metal concentrations (Cd: von Westernhagen et al.

Table 4. Heavy metals in filter feeders. Divergency of results can be attributed to an experimental set-up of laboratory uptake studies not corresponding to a balanced state of organisms with respect to metals in their environment

\begin{tabular}{|c|c|c|c|}
\hline \multicolumn{2}{|c|}{ Laboratory uptake studies } & \multicolumn{2}{|c|}{ Field or laboratory growth } \\
\hline \multicolumn{2}{|c|}{ Biological half-life short ${ }^{a, b . c}$} & \multicolumn{2}{|c|}{ Biological half-life long ${ }^{\text {d.e, }, \mathrm{f}, \mathrm{g}}$} \\
\hline \multicolumn{2}{|c|}{ More uptake when continuously submersed ${ }^{\mathrm{h}}$} & \multicolumn{2}{|c|}{ Tissue concentration lower in subtidal samples ${ }^{f, i, j}$} \\
\hline \multicolumn{2}{|c|}{ Uptake rate higher when given food $\mathrm{d}^{\mathrm{k}, \mathrm{m}, \mathrm{n}}$} & \multicolumn{2}{|c|}{ Tissue concentration lower in well-fed samples ${ }^{f_{0}}$} \\
\hline \multicolumn{2}{|c|}{ Uptake proportional to dissolved $\mathrm{Zn}^{\mathrm{p}, \mathrm{q}, \mathrm{r}}$} & \multicolumn{2}{|c|}{ Zn inadequately indicated ${ }^{\text {s.tu,v,w,x }}$} \\
\hline \multicolumn{2}{|c|}{ Uptake related to ionic speciation ${ }^{\gamma}$} & \multicolumn{2}{|c|}{ Accumulation related to dissolved amount ${ }^{2}$} \\
\hline a Pentreath (1973) & Lobel \& & & s Boyden (1975) \\
\hline b Sturesson (1978) & k Fowler & $(1976)$ & ' Young et al. (1979) \\
\hline - Scholz (1980) & 1 Janssen & 979) & "Phillips \& Yim (1981) \\
\hline${ }^{d}$ Kerfoot \& Jacobs (1976) & m Köhler & 982) & Klumpp \& Burdon-Jones (1982) \\
\hline e Greig \& Wenzloff (1978) & ${ }^{n}$ Borchar & & " Phillips (1985) \\
\hline f Fischer (1983) & - Amiard & & ${ }^{x}$ Fischer (1986b) \\
\hline${ }^{\mathrm{g}}$ Uthe \& Chou (1987) & P d'Silva & 1978) & Y Engel \& Fowler (1979) \\
\hline${ }^{\mathrm{h}}$ Coleman $(1980)$ & q George & & ${ }^{2}$ Fischer (1986a) \\
\hline 'de Wolf (1975) & r Carpen & 1981) & \\
\hline
\end{tabular}


1978, Zaroogian 1980, Ward 1982). Many results from laboratory studies are even in contrast to field observations (Table 4).

Differences between field observations and laboratory results may be attributed to the dominance of short-term studies in experimental work. The 'uptake and loss' type of laboratory studies appears to be governed by the assumption that metals 'equilibrate' between the environment and the tissues of organisms. The corresponding model (Pentreath 1973, Adema 1980) presumes partition equilibria resulting from a balance of uptake and loss. This model predicts rapid loss in a clean environment if uptake had been rapid (see Fig. 5b)

Experimental gradients of dissolved metals may produce 'kinetics' of uptake and loss, but in most metals release plays virtually no role if they were acquired from low ambient levels in the field or the laboratory (Cd: Kerfoot \& Jacobs 1976, Greig \& Wenzloff 1978, Uthe \& Chou 1987). Metals can be bio-chemically complexed and retained by molluscs (reviews: Simkiss \& Mason 1983, Viarengo 1985). This interferes with exchange and equilibration in response to fluctuation of ambient levels. In general, a model of physicochemical partition does not apply to the behaviour of metals in molluscs.

Using an inadequate model may result in confusion. In this context, radiochemical studies require critical consideration. The radio-labelling method depends on complete exchange of isotopes, and partition equilibrium has been implied in relation to metals (e.g. Preston 1971, Pentreath 1973). Since these basic assumptions are not applicable in relation to all heavy metals, conclusions depending on them are questionable, viz. those on uptake routes and biological halflives.

\section{Modelling metal accumulation}

Different transfer rates of metals between organismic compartments, and a 'more or less irreversible' type of binding in one of them, have been proposed by Kečkeš et al. (1968). Their diagram has been modified to visualize a conclusion from the original text (Fig. 4): if there is virtually no exchange of metals between the organismic store and the environment, there must be a net flux of metals through the exchangeable compartment to the irreversibly bound pool. This model appears suitable to illustrate both laboratory and field results on the uptake of metals by molluscs. Short-term experimental studies relate predominantly to the exchangeable fraction of metals in organisms, while binding and storage are more important under field conditions.

$\mathrm{Cd}$ and many other metals are accumulated (in a

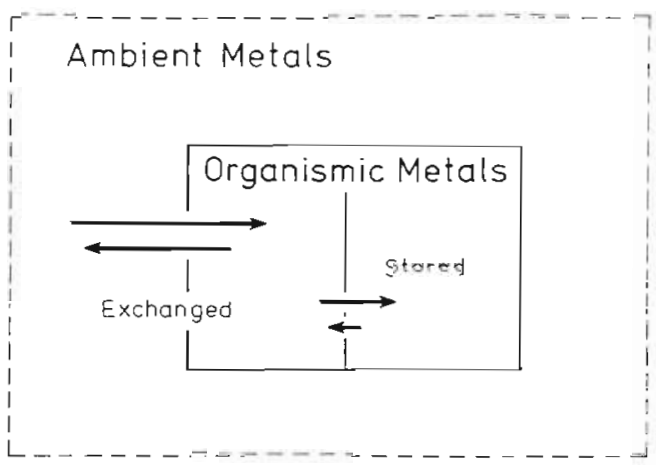

Fig. 4. Diagram of metal transfer and storage in molluscs according to Kečkeš et al. (1968) (modified with permission of the authors). Organismic binding results in a net inflow of metals

strict sense of the term) in molluscs, in that bio-chemical binding and storage results in tissue loads increasing with time. If growth is excluded from the experimental design, the rates of metal uptake are constant and proportional to dissolved concentrations (reviews: Simkiss \& Mason 1983, Bryan 1984), but tissue concentrations increase continuously without approximating a final level (Fig. 5c). This pattern has been observed in many experimental studies on $\mathrm{Cd}$ and other cumulative metals (see also Friedrich \& Filice 1976, Kerfoot \& Jacobs 1976, Ritz et al. 1982, King \& Davies 1987).

When replacing the conventional time scale (Fig. $5 \mathrm{c}$ ) by growth of the independent variable (Fig. $5 \mathrm{~d}$ ) in a model of cumulative binding and storage, it becomes evident that a new equilibrated state of metal levels in organisms may be approximated, depending on growth under new conditions. The relative constancy of metal concentrations in field-collected bivalves results from concomitant growth of soft tissues which compensates the successive uptake

It may be recalled that the soft-tissue weight of molluscs is too variable to provide an appropriate independent variable in relation to $\mathrm{Cd}$ and other cumulative metals. Shell weight has been suggested as an organismic correlate of a similar cumulative character (Fischer 1983). According to a model of bio-chemical accumulation, Cd in molluscs is described by the integral of the $\mathrm{Cd} /$ shell-wt index with growth (by weight) of the shells.

\section{Implications to monitoring and related research}

To develop biological contaminant monitoring and related activities as a branch of science, the divergency between field and laboratory research must be reduced.

Recognizing that experimental uptake rates are proportional to dissolved metal concentrations, several 
Fig. 5. Models in biological contaminant monitoring. (a) Rectangular pulses of ambient contaminant level. (b) Partition equilibrium: rapid equilibration of tissue residues with ambient contaminant levels. (c) Accumulation: derived variable with time. There is no equilibrium if growth of the independent variable is excluded. (d) Accumulation: derived variable with growth of independent variable. A new balanced state may be approximated, depending on growth under new conditions. Small individuals reflect recent changes while large organisms indicate longer-term average contaminant levels. $\mathrm{M}$ : mass of accumulated contaminant
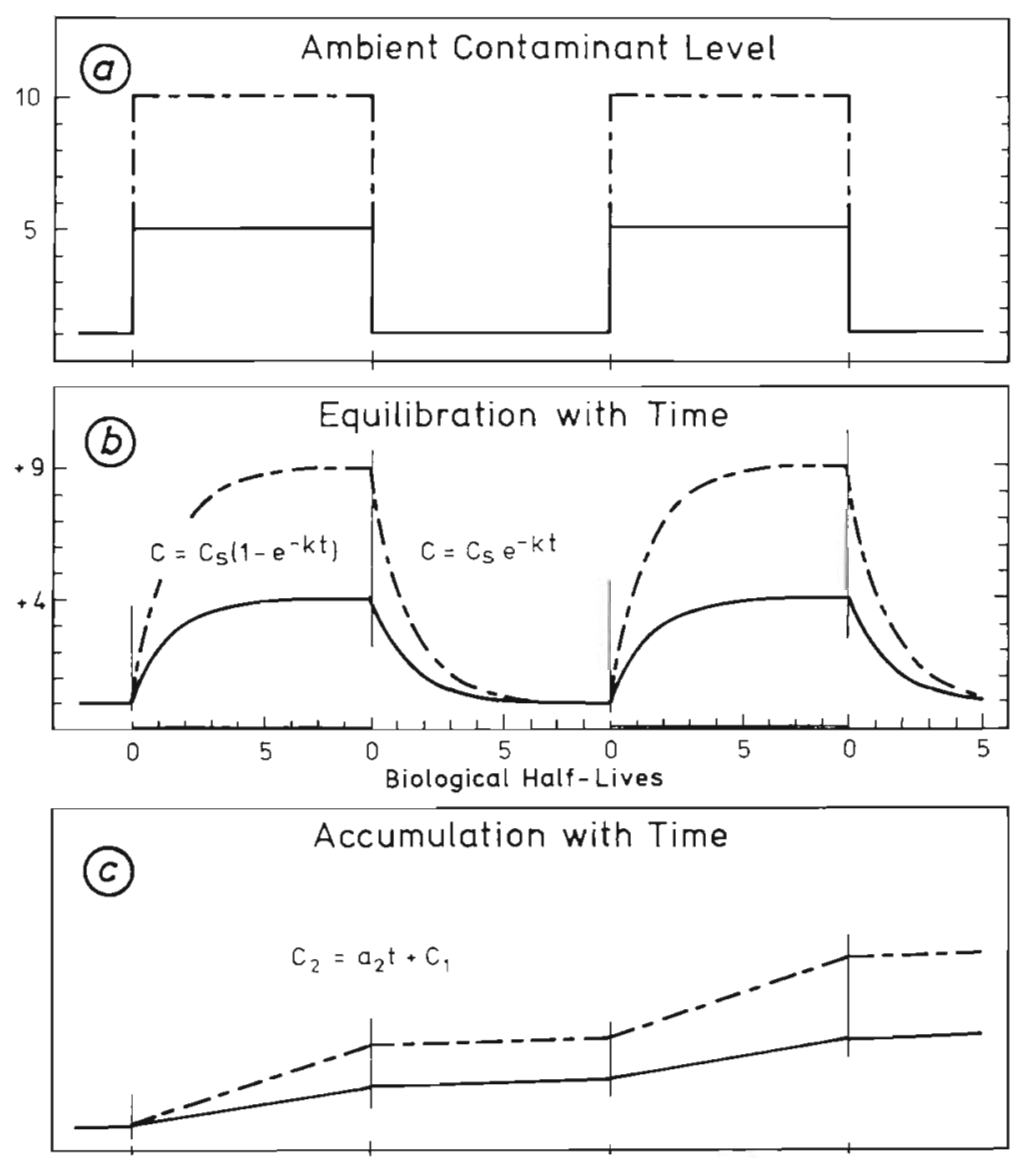

(Short-Term) Time Scale

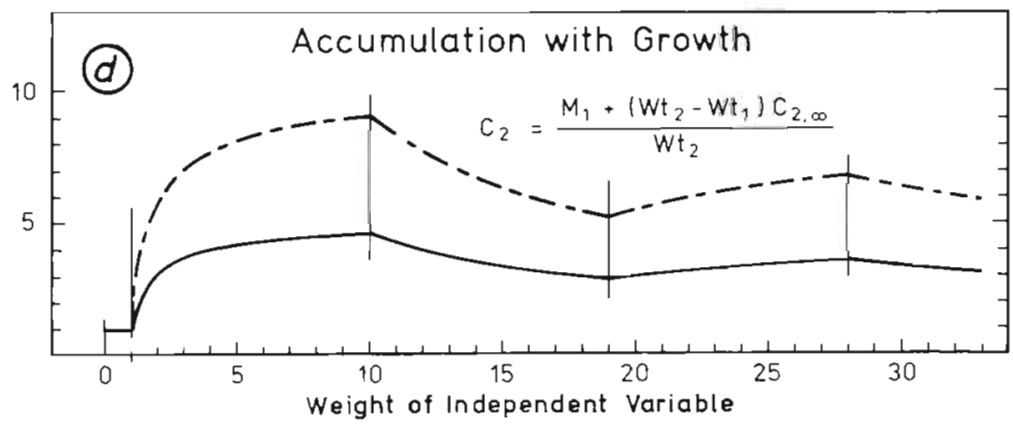

authors (Majori \& Petronio 1973, Ritz et al. 1982; see also Phillips \& Segar 1986) suggested measuring the rates of metal uptake by molluscs transplanted into contaminated environments at short-term intervals. The concentration of metals in the water might then be estimated from the previously obtained laboratory interrelationship between uptake rate and ambient levels. The growth of organisms is explicitly excluded as an uncontrollable factor which would interfere with exactly determining the rates of metal uptake. This approach means following the methodology of shortterm studies in the field.

The method of this study was to approximate a new balanced state of organismic metal residues under con- trolled laboratory conditions. The concentration of metals in the natural environment might then be estimated from field surveillance data in comparison with the experimental interrelationship between ambient levels and organismic residues. This approach depends on growth in the environment concerned, according to a model of bio-chemical accumulation. It represents an attempt towards improved simulation of field conditions in the laboratory.

The growth model (Fig. 5d) conforms with the assumption that larger (older) individuals indicate a long-term average level of ambient metals, while small (young) specimens are influenced by recent changes. Consequently, large specimens should not be analysed 
where investigations are intended to detect short-term changes. In any case, laboratory and field transplant experiments should be performed with small (juvenile) specimens, allowing them to grow as much as possible in their new environment.

\section{SUMMARY AND PROSPECTS}

Research on $\mathrm{Cd}$ in the mussel has demonstrated that estimating the bio-available concentration of a metal in coastal seawater from 'mussel watch' data is feasible. The procedure suggested may be applied in field surveillance programmes. It depends on referring tissue residues of $\mathrm{Cd}$ to the weight of shells $(\mathrm{Cd} /$ shells-wt index) according to a model of bio-chemical accumulation. This model requires growth in the environment concerned to produce reliable data on contaminant residues, both in the field and in the laboratory.

There is as yet no evidence that quantitative biomonitoring of metals other than $\mathrm{Cd}$ is possible. In particular, factual independency of co-factors other than $\mathrm{Zn}$ (and salinity) may be a peculiarity of $\mathrm{Cd}$ binding in the soft tissue of molluscs. However there is some justification to assume that many non-essential metals follow a similar pattern (Amiard et al. 1986, Dahlgaard 1986). Further research and substantiation is needed. Scientific progress may depend on identifying specific pathways and storage sites of metals in molluscs. In this respect deposition of metals in shells (Sturesson 1976) may be given renewed attention (Goldberg 1986).

At present, metal/shell-wt indices provide a method to detect minor differences and changes in the availability of cumulative metals (and other such contaminants) to molluscs. In addition to detecting unknown sources of contamination, refined bio-monitoring techniques may be particularly useful to quantify processes in the sea by which the availability of contaminants to biota is modified, such as the formation of sulfur compounds in anoxic bottom water (Fischer 1986c). Since the condition index reflects nutrition, recording shell weight in field surveillance programmes (e.g. ICES 1984, BMU 1987) provides the additional option of evaluating a broad data base with respect to eutrophication (Fischer $1986 \mathrm{a}, \mathrm{c}$ ) - a formidable problem in many coastal environments (Goldberg 1982). The need to have organisms grow to approximate a new steady-state equilibrium of contaminant residues suggests using effects on growth as an ecologically valid response to contaminants (Bryan 1971, Fischer 1986b, this study: Fig, 3). These aspects appear promising to increase the potential of the imussel watch', but further investigations are required to establish (or reject) their significance.
Acknowledgements. The experimental and analytical work of this study was performed at the Institut für Meereskunde an der Universität Kiel, under the sponsorship of the Umweltbundesamt (UBA F\&E-Vorhaben Wasser 10607 033). Laboratory assistance was ably provided by Monika Westphal and Silke $\checkmark$. Bismarck. Thanks are due to Prof. $\mathrm{H}$. Theede for granting full scope.

\section{LITERATURE CITED}

Adema, D. M. M. (1980). Determination of bio-accumulation and bioelimination. In: Degradability, ecotoxicity and bioaccumulation. Government Publishing Office, The Hague p. II-255-272

Amiard, J. C., Amiard-Triquet, C., Berthet, B., Métayer, C (1986). Contribution to the exotoxicological study of cadmium, lead, copper and zinc in the mussel Mytilus edulis. I. Field study. Mar. Biol 90: 425-431

Berman, S. S., Boyko, V J. (1987). ICES seventh round intercalibration for trace metals in biological tissue. ICES 7/ TM/BT (Part 2) Preliminary report. National Research Council, Ottawa

Berthet, B., Amiard-Triquet, C., Métayer, C., Amiard, J. C. (1984). Etude écologique de l'accumulation de quelques éléments traces chez la moule et dans certains composants đ'un écosystème de zone conchylicole. J. Rech. Océanogr 9: 75-7

Betz, M. (1977). Investigations on the simultaneous uptake and release of mercury by Dunaliella tertiolecta. Mar. Biol. 41: 89-97

BMU (Bundesminister für Umwelt, Naturschutz und Reaktorsicherheit) (1987). Contribution of the Federal Republic of Germany to the Joint Monitoring Programme of the Oslo and Paris Commissions. Working Programme 1986-1995. BMU - U III 4, Bonn

Boje, R. (1965). Die Bedeutung von Nahrungsfaktoren für das Wachstum von Mytilus edulis L. in der Kieler Förde und im Nord-Ostsee-Kanal. Kieler Meeresforsch. 21 81-100.

Borchardt, T. (1985). Relationship between carbon and cadmium uptake in Mytilus edulis. Mar. Biol. 85: 233-244

Boyden, C. R. (1975). Distribution of some trace metals in Poole Harbour, Dorset. Mar Pollut. Bull. 6: 180-187

Bryan, G. W. (1971). The effects of heavy metals (other than mercury) on marine and estuarine organisms. Proc. R. Soc Lond. B 177: 389-410

Bryan, G. W (1984). Pollution due to heavy metals and their compounds. In: Kinne, O. (ed.) Marine ecology, Vol. V, Ocean management, Part 3. Wiley \& Sons, Chichester, $p$ 1289-1431

Bryan, G. W., Gibbs, P. E. (1983). Heavy metals in the Fal Estuary, Cornwall: a study of Iong-term contamination by mining waste and its effects on estuarme organisms. Mar. biol. Ass. U. K., Occas. Publ. 2: 1-112

Butler, P.. Andrén, L. E, Bonde, G. J., Jernelöv, A. B., Reish, D. J. (1971). Monitoring organisms. FAO Fish. Rep. 99 (Suppl. 1): $101-112$

Carlson, H. (ed.) (1986). Quality status of the North Sea. Dt. hydrogr. Z. (Erg.-H. B) Nr 16

Carpene, E., George, S. G. (1981). Absorption of cadmium by Mytilus edulis gills. Molecular Physiology 1 23-34

Chester, R, Stoner, J. H. (1974). The distrbution of zinc, nickel, manganese, cadmium, copper, and iron in some surface waters from the world ocean. Mar. Chem. 2.17-32

Coleman, N. (1980). The effect of emersion on cadmium accumulation by Mytilus edulis. Mar. Pollut. Bull. 11 $359-362$ 
Dahlgaard, H. (1986). Effects of season and temperature on long-term in situ loss rates to $\mathrm{Pu}, \mathrm{Am}, \mathrm{Np}, \mathrm{Eu}, \mathrm{Ce}, \mathrm{Ag}, \mathrm{Tc}$ Zn, Co and Mn in a Baltic Mytilus edulis population. Mar. Ecol. Prog. Ser. 33: 157-165

Department of the Environment (ed.) (1987). Quality status of the North Sea. Report by the Scientific and Technical Working Group for the Second International Conference on the Protection of the North Sea, London, 24-25 Nov 1987

de Wolf, P. (1975). Mercury content of mussels from West European coasts. Mar. Pollut. Bull. 6: 61-63

d'Silva, C., Kureishy, T. W (1978). Experimental studies on the accumulation of copper and zinc in the green mussel Mar. Pollut. Bull. 9: 187-190

Engel, D. W., Fowler, B. A. (1979). Factors influencing cadmium accumulation and its toxicity to marine organisms. Environ. Hlth Perspect. 28: 81-88

Fischer, H. (1983). Shell weight as an independent variable in relation to cadmium content of molluscs. Mar. Ecol. Prog Ser. 12: $59-75$

Fischer, H. (1986a). Influence of temperature, salinity, and oxygen on the cadmium balance of mussels Mytilus edulis. Mar. Ecol. Prog. Ser. 32: 265-278

Fischer, H. (1986b). Zinc and cadmium in mussels (Mytilus edulis L.): dose/response relationships and water quality contral. Coun. Meet. int. Coun. Explor. Sea, C. M.-ICES/E: 23, p. $1-14$

Fischer, H. (1986c). Cadmium in Kieler Förde mussels: an innovative monitoring programme. Rapp. P.-v. Réun. Cons. int. Explor. Mer 186: 468-474

Fowler, S. W., Benayoun, G. (1976). Influence of environmental factors on selenium flux in two marine invertebrates. Mar. Biol. 37: 59-68

Friedrich, A. R., Filice, F. P. (1976). Uptake and accumulation of the nickel ion by Mytilus edulis. Bull. Environ. Contam. Toxicol. 16: 750-755

George, S. G., Pirie, B. J. S. (1980). Metabolism of zinc in the mussel, Mytilus edulis (L.): a combined ultrastructural and biochemical study. J. mar biol. Ass. U. K. 60: 575-590

Goldberg, E. D. (1975). The mussel watch - a first step in global marine monitoring. Mar Pollut. Bull. 6: 111

Goldberg, E. D. (1982). Problems or non-problems (Editorial). Mar Pollut. Bull. 13: 1

Goldberg, E. D. (1986). The mussel watch concept. Environ. Monit. Assess. 7: 91-103

Goldberg, E. D., Bowen, V. T., Farrington, J. W., Harvey, G. Martin, J. H., Parker, P. L., Risebrough, R. W., Robertson, W., Schneider, E., Gamble, E. (1978). The mussel watch. Environ. Conserv. 5: 101-125

Greig, R. A., Wenzloff, D. R. (1978). Metal accumulation and depuration by the American oyster Crassostrea virginica. Bull. Environ. Contam. Toxicol. 20: 499-504

IAWR (Internationale Arbeitsgemeinschaft der Wasserwerke im Rheineinzugsgebiet) (1980). Rheinbericht 1978. In: Der Rat von Sachverständigen für Umweltfragen (ed.) Umweltprobleme der Nordsee. Kohlhammer, Stuttgart, p. 88-89

ICES/Advisory Committee on Marine Pollution (1984). Plans for the 1985 baseline study of contaminants in fish and shellfish. In: ICES (ed.) Cooperative research report 132. ICES, Charlottenlund, p. 113-118

Jackim, E., Morrison, G., Steele, R. (1977). Effects of environmental factors on radiocadmium uptake by four species of marine bivalves. Mar. Biol. 40: 303-308

Janssen, H. H., Scholz, N. (1979). Uptake and cellular distribution of cadmium in Mytilus edulis. Mar. Biol. 55: 133-141

Kägi, J. H. R., Nordberg, M. (eds.) (1979). Metallothionein. Birkhäuser, Basel
Kečkeš, S., Ozretić, B., Kraijnović, M. (1968). Loss of Zn-65 in the blue mussel Mytilus galloprovincialis. Malacologia 7 $1-6$

Kerfoot, W B., Jacobs, S. A. (1976). Cadmium accrural in combined wastewater-treatment aquaculture system. Environ. Sci. Technol. 10: 662-667

King, D. G., Davies, I. M. (1987) Laboratory and field studies on the accumulation of inorganic mercury by the mussel Mytilus edulis (L.). Mar. Pollut. Bull. 18: 40-45

Kinne, O. (1970). International symposium 'Cultivation of marine organisms and its importance in marine biology': Closing address. Helgoländer wiss. Meeresunters. 20: $707-710$

Kinne, O. (1984). Introduction to part 3 - Pollution and protection of the seas: radioactive materials, heavy metals, and oil. In: Kinne, O. (ed.) Marine ecology Vol. V, Part 3. Wiley \& Sons, Chichster, p. 1091-1110

Klumpp, D. W., Burdon-Jones, C. (1982). Investigation of the potential of bivalve molluscs as indicators of heavy metals in tropical waters. Aust. J. mar. Freshwat. Res. 33: 285-300

Köhler, K., Riisgård, H. U. (1982). Formation of metallothioneins in relation to accumulation of cadmium in the common mussel Mytilus edulis. Mar. Biol. 66: 53-58

Kremling, K., Otto, C., Petersen, H. (1979). SpurenmetallUntersuchungen in Förden der Kieler Bucht. Ber. Inst. Meeresk. Univ. Kiel 66: 1-38

LA-SH (Landesamt für Wasserhaushalt und Küsten Schleswig-Holstein) (1979-1982). Gewässerüberwachung 1978-1981. LA-SH, Kiel

Lobel, P. B., Wright, D. A. (1982). Total body zinc concentration and allometric growth ratios in Mytilus edulis collected from different shore levels. Mar Biol. 66: 231-236

Majori, L., Petronio, F. (1973). Marine pollution by metals and their accumulation by biological indicators (accumulation factor). Rev. Int. Océanogr. Méd. 31-32: 55-90

NRCC (National Research Council Canada) (1985). CASS-1 nearshore seawater reference material for trace metals. NRCC, Ottawa

Pentreath, R. J. (1973). The accumulation from water of ${ }^{65} \mathrm{Zn}$, ${ }^{54} \mathrm{Mn},{ }^{58} \mathrm{Co}$ and ${ }^{59} \mathrm{Fe}$ by the mussel Mytilus edulis. J. mar. biol. Ass. U. K. 53: 127-143

Phillips, D. J. H. (1976). The common mussel Mytilus edulis as an indicator of pollution by zinc, cadmium and copper. I. Effects of environmental variables on uptake of metals. Mar Biol. 38: 59-69

Phillips, D. J. H. (1980). Quantitative aquatic biological indicators. Applied Science Publishers, London

Phillips, D. J. H. (1985). Organochlorines and trace metals in green-lipped mussels Perna viridis from Hong Kong waters: a test of indicator ability. Mar. Ecol. Prog. Ser. 21: 251-258

Phillips, D. J. H., Segar, D. A. (1986). Use of bio-indicators in monitoring conservative contaminants: programme design imperatives. Mar. Pollut. Bull. 17: 10-17

Phillips, D. J. H., Yim, W W. S. (1981). A comparative evaluation of oysters, mussels and sediments as indicators of trace metals in Hong Kong water. Mar. Ecol. Prog. Ser. 6 : 285-293

Preston, E. M. (1971). The importance of ingestion in chromium-51 accumulation by Crassostrea virginica (Gmelin). J. exp. mar. Biol. Ecol. 6: 47-54

Riisgård, H. U., Randløv, A., Kristensen, P. S. (1980). Rates of water processing, oxygen consumption and efficiency of particle retention in veligers and young post-metamorphic Mytilus edulis. Ophelia 19:37-47

Ritz, D. A., Swain, R., Elliot, N. G. (1982). Use of the mussel Mytilus edulis planulatus (Lamarck) in monitoring heavy 
metals in seawater. Aust. J. mar. Freshwater Res. 33: 491-506

Scholz, N. (1980). Accumulation, loss and molecular distribution of cadmium in Mytilus edulis. Helgoländer Meeresunters. 33: $68-78$

Simkiss, K., Mason, A. Z. (1983). Metal ions: metabolic and toxic effects. In: Hochachka, P. W. (ed.) The Mollusca, Vol. 2 - Environmental biochemistry and physiology. Academic Press, New York, p. 101-164

Sperling, K.-R. (1985). Cadmiumbestimmungen in Küstenwasserproben aus der Deutschen Bucht. Vom Wasser 64 : $53-68$

Sturesson. U. (1976). Lead enrichment in shells of Mytilus edulis. Ambio 5: 253-256

Sturesson, U. (1978). Cadmium enrichment in shells of Mytilus edulis. Ambio 7: 122-125

Uthe, J. F., Chou, C. L. (1987). Cadmium in sea scallop (Placopecten magellanicus) tissues from clean and contaminated areas. Can. J. Fish. Aquat. Sci. 44: 91-98

Vallee, B. L. (1978). Zinc biochemistry and physiology and their derangements. In: Williams, R. P. J., DaSilva, J. R. R. $F$. (eds.) New trends in bio-inorganic chemistry. Academic Press, London, p. 11-57
Vallee, B. L, Ulmer, D. D. (1972). Biochemical effects of mercury, cadmium and lead. A. Rev. Biochem. 41 91-128

Viarengo, A. (1985). Biochemical effects of trace metals. Mar. Pollut. Bull. 16: 153-158

Ward, T J. (1982). Laboratory study of the accumulation and distribution of cadmium in the Sydney rock oyster Saccostrea commercialis (I \& R). Aust. J. mar. Freshwat. Res. 33: $33-44$

Westernhagen, H. von, Dethlefsen, V., Rosenthal, H., Fürstenberg, G, Klinckmann, J. (1978). Fate and effects of cadmium in an experimental marine ecosystem. Helgoländer wiss. Meeresunters. 31: 471-484

White, H. H. (1984). Mussel madness: use and misuse of biological monitors of marine pollution. In: White, $\mathrm{H}$. $\mathrm{H}$. (ed.) Concepts in marine pollution measurements. Maryland Sea Grant College, College Park, MD 20742, p. 325-337

Young, D. R., Alexander, G. V., McDermott-Ehrlich, D. (1979). Vessel-related contamination of Southern California Harbours by copper and other metals. Mar. Pollut. Bull. 10: $50-56$

Zaroogian, G. E. (1980). Crassostrea virginica as an indicator of cadmium pollution. Mar Biol. 58: 275-284

This article was submitted to the editor; it was accepted for printing on July 8, 1988 